\title{
Vitamin E Changes Erythrocyte and Leukocyte Levels in Male Rats (Mus musculus) Due to Strenuous Exercise
}

\author{
Sugiharto ${ }^{1}$, Mohammad Arif $\mathrm{Ali}^{1}$, Anies Setiowati ${ }^{1}$, \\ ${ }^{1}$ Department of Sports Sciences, Faculty of Sports Sciences, Semarang State University \\ (UNNES), Central Java 50229, Indonesia \\ sugiharto.ikor@mail.unnes.ac.id ${ }^{1}$, hiarifalikhan@mail.unnes.ac.id, \\ setiowatianies@mail.unnes.ac.id
}

\begin{abstract}
Oxidative stress can be induced by strenuous exercise either in human or in animal, it can damages erythrocyte during and post-exercise. Furthermore, maximum exercise also affecting leukocyte level. In another hand that vitamin $\mathrm{E}$ as an agent of antioxidant might be potentially can be a protector for damage erythrocyte and leukocyte caused by strenuous exercise. The purpose of this study was to investigate effects of vitamin E $0.2 \mathrm{mg}$ and $0.4 \mathrm{mg}$ on the change of erythrocyte and leukocyte levels in male rats (Mus musculus) due to strenuous exercise for twenty eight days. Randomized post-test controlled group design was used in this study. Twenty male rats (2-4 months old) were divided into four groups: 1) Control Group (G1); 2) Strenuous Exercise Group (G2); 3) Strenuous Exercise Group + $0.2 \mathrm{mg}$ of vitamin E (G3); 4) Strenuous Exercise Group + $0.4 \mathrm{mg}$ of vitamin E (G4). Strenuous exercise had given every day for 28 days. One-way ANOVA and Post Hoc Tukey was performed to analyze the data. The results showed that the erythrocyte level of strenuous exercise group (G2) was lowest compared to G1, G3, and G4 $(P<.05)$ as well as the leukocyte level as the $P$-value $<.05$. The conclusion is the treatment of vitamin $\mathrm{E}$ is able to prevent the damage of erythrocyte and to maintain the steady level of leukocyte due to strenuous.
\end{abstract}

Key words: antioxidant, strenuous exercise, blood parameters

\section{INTRODUCTION}

Oxidative stress can be produced by strenuous exercise either in rats or in human, (Senturk et al, 2001; Senturk et al, 2005). It is one of many factors which responsible on the erythrocyte damaged (due to an exposure the damage occurred in lipid membrane, especially when the cells passed the micro-circulation) during and post physical exercise, (Senturk et al, 2001; Senturk et al, 2005; Telford et al, 2002). Furthermore, the profile of erythrocyte (hematocrit, hemoglobin and erythrocyte) can be used to be the indicator of oxidative status. Erythrocyte is the main location of free radical production and leads to peroxidation of fatty acid on phospholipid membrane which eventually it changes the quality (integrity and the cell size) and also the quantity of erythrocyte, (Pearce et al, 2003; Kiron et al, 2004).

During maximum physical exercise there is an incident of power stroke, sliding filament and disconnecting at cross bridge cycle which is actually a mechanical trauma and can leads to muscle injury (Len et al, 2002). In the injury tissue chemo attractant will be released to attract 
leukocyte especially neutrophil to the muscle injured cite, followed by the construction of reactive oxygen species (ROS) which is used as body protection. In the normal metabolism ROS production is equated with endogenous antioxidants such as superoxide dismutase (SOD), glutathione peroxide (GPx), and Catalase. When the production of ROS is slightly higher than the antioxidant (vice versa), then oxidative stress will be occurred, (Shojaei et al, 2010).

Oxidative stress can cause increased body temperature, inflammation and activation of leukocyte, (Harjanto, 2004). Right after the tissue injured, leukocyte will quickly migrates and gathered in the injured tissue. Chemical signal which released from the injured tissue is an inductor factor of leukocytosis. This factor diffuse from inflammation tissue into the blood stream and it goes to spinal cord which leads leukocyte especially neutrophil to be released, (Guyton and Hall, 2008). The increased of leukocyte (can be more than 10.000 cells/ $\mu \mathrm{L}$ ) as a physiological response of the immune system, (Gokhan et al, 1992). In the seventh day post physical exercise the balance of antioxidant system would be back to the normal condition/metabolism, therefore the neutrophil level would be decreased, (Cooper, 2002). Leukocyte has a role in the immune system. The peripheral leukocyte levels can be used as the indicator to diagnosis and prognosis about the damage status of tissue or organ and also to predict the recovery after physical exercise, (Sodique et al, 2000).

Vitamin $\mathrm{E}$ as an antioxidant agent is able to protects cell membrane from the damage caused by endogenous free radical (lipid peroxidation) which produced by its own normal metabolism in the body, as well as the free radical which produced by the outside such as ultraviolet (UV) or air pollution. Vitamin $\mathrm{E}$ as a hydrogen $(\mathrm{H}+)$ donor is capable to changes peroxide radical to be a tocopherol radical by giving its hydrogen ion (un-active form) therefore it is unable to attack the fatty acids chain, (Lukman, 2003).

Previous (animal) studies conducted by Yustini and Elmatris in 2009 showed that the exposure by UV for 6 hours per day for three weeks induced the decreased of erythrocyte, and the reduction can be spared by vitamin $\mathrm{E}$ treatment $(0.45 \mathrm{IU} / \mathrm{kg}$ bw/1X/day). Moreover, Nongrong in 2011 by using vitamin E $(0.33 \mathrm{mg} /$ day $)$ on exposure of palm wine for thirty days, it can increased the amount of reticulocyte, the amount of erythrocyte, and also able to repair the damage morphology of erythrocyte, increased the hemoglobin as well as the hematocrit. Additionally, a human study conducted by Kristo in 2016, the neutrophil level was increased after physical exercise for 60 minutes, and by the treatment of $400 \mathrm{IU}$ of vitamin $\mathrm{E}$ for a week there was significantly differences compared to control group as $P .05$.

Based on the elucidation above, the purpose of this study was to investigate effects of vitamin E $0.2 \mathrm{mg}$ and $0.4 \mathrm{mg}$ on the change of erythrocyte and leukocyte levels in male rats (mus musculus) due to strenuous exercise for twenty eight days.

\section{METHODS}

Design, Material and Procedure. This is an experimental laboratory research study (Randomized post-test controlled group design). The independent variable in this study is vitamin $\mathrm{E}$, while the dependent variable is erythrocyte and leukocyte levels. It was conducted at laboratory of biology, Faculty of Math and Sciences, Semarang State University (Universitas Negeri Semarang). Twenty male rats (Mus musculus) aged 2-3 months were divided into four groups, 1) Control group (G1), 2) Strenuous exercise group (G2), 3) Strenuous exercise group $+0.2 \mathrm{mg}$ of Vitamin E (G3), and 3) Strenuous exercise group + $0.4 \mathrm{mg}$ of Vitamin E (G4). The following procedure was implemented: 1) All subjects were familiarized for seven days. 2) Ad libitum feeding was applied and free access to water. 3) Rats qualified for the research were used. 4) Rats were 
randomized divided into four groups then received the treatments. 5) The measurement of erythrocyte and leukocyte levels performed after strenuous exercise in the last day of experiment. The study procedures were approved by the Institutional Animal Study Committee of Faculty of Math and Sciences, Semarang State University (Universitas Negeri Semarang).

Strenuous Exercise for 28 days, 30 minutes swimming each exercise session, 5 times in a week not including 7 days of familiarization, in the last day of experiment the measurement of erythrocyte and leukocyte levels was did.

Pure Vitamin E (powder) dissolved in the water was used in this study.

$1 \mathrm{mg}=1.49 \mathrm{IU}$

$1 \mathrm{IU}=1 / 1.49=0.67 \mathrm{mg}$

Human $=120 \mathrm{IU} /$ day $=80 \mathrm{mg} /$ day

Rats $($ Mus musculus $)=0.0026 \times 80 \mathrm{mg}=0.208 \mathrm{mg} /$ day in $0.5 \mathrm{~mL}$ of $\mathrm{H}_{2} \mathrm{O}$

The measurement of erythrocyte and leukocyte levels, blood taken from orbital sinus by using micro-hematocrit pipet, then blood was placed in the centrifuge tube. The measurement of erythrocyte and leukocyte levels performed by loading the blood into pipet which is contained Ethylene Diamine Tetra Acetic Acid (EDTA) and Turk solution (to calculate the amount of leukocyte) also Hayem solution (to calculate the amount of erythrocyte), then Improved Neubaeur was used to calculate under the microscope with $100 \mathrm{X}$ enlargement.

Data Analysis. The data were expressed as the means \pm standard errors of the mean (SEMs). One-war ANOVA (post Hoc Tukey) was used to determine whether there were any effects of vitamin E on erythrocyte and leukocyte levels. A level of $P<.05$ was considered statistically significant. SPSS 16 was performed.

\section{RESULTS}

The erythrocyte level in Strenuous Exercise Group (G2) was significantly lowest $(4.61 \pm 0.82)$ million $/ \mathrm{mm}^{3}$ compared to the control group (G1) $(7.50 \pm 0.72) \mathrm{million} / \mathrm{mm}^{3}$, to the Strenuous Exercise Group $+0.2 \mathrm{mg}$ of vitamin E (G3) $(7.99 \pm 1.11) \mathrm{million} / \mathrm{mm}^{3}$, also to the Strenuous Exercise Group $+0.4 \mathrm{mg}$ of vitamin E (G4) $(8.17 \pm 0.72) \mathrm{million} / \mathrm{mm}^{3}(P<.05)$.

The leukocyte level in Strenuous Exercise Group (G2) was significantly lowest $(8.45 \pm 0.74)$ thousand $/ \mathrm{mm}^{3}$ compared to the control group (G1) $(11.06 \pm 1.58)$ thousand $/ \mathrm{mm}^{3}$, to the Strenuous Exercise Group $+0.2 \mathrm{mg}$ of vitamin E (G3) $(11.34 \pm 1.15)$ thousand $/ \mathrm{mm}^{3}$, also to the Strenuous Exercise Group $+0.4 \mathrm{mg}$ of vitamin E (G4) $(12.25 \pm 1.22)$ thousand $/ \mathrm{mm}^{3}(P<.05)$.

Table 1. Effects of vitamin $E$ towards erythrocyte and leukocyte levels in male rats (mus musculus) after strenuous exercise

\begin{tabular}{|c|c|c|c|c|c|}
\hline \multirow{2}{*}{$\begin{array}{c}\text { Variable } \\
n=5\end{array}$} & \multicolumn{4}{|c|}{ Experimental Groups } & \multirow{2}{*}{$P$} \\
\hline & G1 & G2 & G3 & G4 & \\
\hline $\begin{array}{l}\text { Erythrocyte } \\
\left(\text { million/mm } / \mathrm{mm}^{3}\right)\end{array}$ & $7.50 \pm 0.72$ & $4.61 \pm 0.82$ & $7.99 \pm 1.11$ & $8.17 \pm 0.72$ & 0.000 \\
\hline $\begin{array}{l}\text { Leukocyte } \\
\text { (thousand } / \mathrm{mm}^{3} \text { ) }\end{array}$ & $11.06 \pm 1.58$ & $8.45 \pm 0.74$ & $11.34 \pm 1.15$ & $12.25 \pm 1.22$ & 0.001 \\
\hline
\end{tabular}

Effects of vitamin E towards erythrocyte and leukocyte levels then to be analysed more by using Post Hoc Tukey, can be seen in the table 2 (erythrocyte) and table 3 (leukocyte). The 
Post Hoc Tukey test showed that G2 group compared to other experimental groups (G1, G3, and G4) respectively, there is significantly difference in erythrocyte level as $P$ value $<.05$. Further, there is no significantly difference between G1 (control group) to G3 (Strenuous Exercise Group $+0.2 \mathrm{mg}$ of vitamin E) as $P$ value $>.05$; between G1 (control group) to G4 (Strenuous Exercise Group $+0.4 \mathrm{mg}$ of vitamin $\mathrm{E})(P>.05)$. Furthermore, there is no significantly difference in erythrocyte level between G3 to G4 as $P$ value $>.05$. Therefore can be concluded that strenuous exercise program for 28 days is able affecting the decreased of erythrocyte level, and both treatments of vitamin E $0.2 \mathrm{mg}$ and $0.4 \mathrm{mg}$ are able to inhibits the decreased of erythrocyte level, however the different dosage of vitamin $\mathrm{E}$ does not showed the different effect.

Table 2. Post Hoc Tukey was used to determine effect of vitamin E towards erythrocyte level in male rats (Mus musculus) after strenuous exercise

\begin{tabular}{|c|c|c|c|c|}
\hline \multirow{2}{*}{$\begin{array}{c}\text { Experimental } \\
\text { Groups }\end{array}$} & \multicolumn{4}{|c|}{$P$} \\
\cline { 2 - 5 } & G1 & G2 & G3 & G4 \\
\hline G1 & - & 0.000 & 0.808 & 0.618 \\
\hline G2 & 0.000 & - & 0.000 & 0.000 \\
\hline G3 & 0.808 & 0.000 & - & 0.987 \\
\hline G4 & 0.618 & 0.000 & 0.987 & - \\
\hline
\end{tabular}

The Post Hoc Tukey test showed that G2 (Strenuous Exercise Group) group compared to other experimental groups (G1, G3, and G4) respectively, there is significantly difference in leukocyte level as $P$ value $<.05$. The result in leukocyte is similar like in erythrocyte that there is no significantly difference between G1 to G3 and G1 to G4. Furthermore, there is also no significantly difference in leukocyte level between G3 to G4 as $P$ value $>.05$. It means that strenuous exercise has big impact on the lowest of leukocyte level in group without vitamin $\mathrm{E}$ treatments $(\mathrm{G} 2)$ compared to all of experimental groups.

Table 3. Post Hoc Tukey was used to determine effect of vitamin E towards leukocyte level in male rats (Mus musculus) after strenuous exercise

\begin{tabular}{|c|c|c|c|c|}
\hline \multirow{2}{*}{$\begin{array}{c}\text { Experimental } \\
\text { Groups }\end{array}$} & \multicolumn{4}{|c|}{$P$} \\
\cline { 2 - 5 } & G1 & G2 & G3 & G4 \\
\hline G1 & - & 0.014 & 0.981 & 0.408 \\
\hline G2 & 0.014 & - & 0.007 & 0.001 \\
\hline G3 & 0.918 & 0.007 & - & 0.623 \\
\hline G4 & 0.408 & 0.001 & 0.623 & - \\
\hline
\end{tabular}




\section{DISCUSSION}

Result of this study showed that the erythrocyte level in group 2 (strenuous exercise group) is lowest compared to all the experimental groups. The theory of physical excercise induce free radical which leads damaged erythrocyte has proved. Interestingly, The damaged erythrocyte caused by free radical seems can be inhibited with an antioxidant agent which is vitamin E. Further, results showed that the erythrocyte level was higher in group with strenuous exercise compared to all the experimental groups. The treatments of vitamin E $0.2 \mathrm{mg}$ and $0.4 \mathrm{mg}$ seem could spare the increased of erythrocyte level after strenuous exercise. Moreover, exposured by free radical due to physical exercise, there are some factors that can cost the damaged erythrocyte caused by exercise such as gastrointestinal and urinary track bleeding, lost of iron, lack of erythropoesis and more probability that can cause an anemia, the primary among these mechanisms is hemolysis intravasculer. Mechanical trauma (foot-strike or erythrocyte compression in capilar which occured during muscle contraction), the increased of body temperature, dehydration, hemoconcentration and oxidative stress that occured during physical exercise and at the recovery stage then to be known cause the hemolysis intravasculer. The damaged erythrocyte occured during and after strenuous physical exercise and can leads into anemia condition, which is known as sport anemia, (Sentruk et al, 2001).

The statistical result showed there is no significantly difference in the amount of erythrocyte between control group compared to groups with vitamin E, tells us that the treatment of vitamin $\mathrm{E}$ was successfully prevent the damaged erythrocyte, and the different in dosage $(0.2$ $\mathrm{mg}$ and $0.4 \mathrm{mg}$ ) did not show any better effect. According to study by Sentruk in 2005 that treatment of vitamin E $800 \mathrm{mg}$ and physical exercise for 2 months showed exercise induced oxidative stress was prevented based on osmotic fragility and deformability of erythrocytes, plasma hemoglobin concentration, and haptoglobulin levels were not changed after exercise, although the increased oxidative stress was observed in trained subjects. However, antioxidant vitamin treatment, functional and structural parameters of erythrocytes were not changed in the trained group. Moreover, exercise also induces immune like response, results leukocytosis that is quantitatively similar to the response against physiological insults to immune system. The leucocytosis of exercise has been often compared to inflammation like reaction. The exercise induced increase of neutrophils was previously described to be at least partially due to increased cortisol levels in the blood (Bhatti, 2007).

In this study showed that lowest level of leukocyte only found in strenuous exercise group compared to control group or groups with vitamin $\mathrm{E}$ treatment. It might be caused by the strenuous exercise treatment for 28 days, 30 minutes swimming each exercise session, 5 times in a week. Leukopenia occurred dominantly by damaged leukocyte due to free radical. Further, there is no difference in the leukocyte level in control group compared to experimental groups with vitamin $\mathrm{E}$. This shows that vitamin $\mathrm{E}$ treatment as an exogenous antioxidant is able to support the endogenous antioxidant catalase to inhibit the production of free radical Reactive Oxygen Species (ROS) due to strenuous exercise. In physiological condition the ROS can be eliminated by catalase, however in some cases which ROS production is much higher like in exercise, the presence of vitamin $\mathrm{E}$ as antioxidant agent is really needed. Vitamin $\mathrm{E}$ as the exogenous antioxidant is able to protect cellular membrane and subcellular, erythrocyte and leukocyte from the damage caused by free radical because of saturated lipid peroxidation which resulted by normal metabolism and by long-term strenuous physical exercise, (Lukman, 2003). 


\section{REFERENCES}

1. Bhatiti, R., Shaikh, DM.,The Effect Of Exercise on Blood Parameter.Pak J Physiol 2007;3(2)

2. Cooper CE, Vollaard BJ, Choueiri T, Wilson MT. Exercise, free radicals and oxidative stress. Biochemical society. 2002;30(2):280-5.

3. Evans, W. J. (2000), Vitamin E, vitamin C, and exercise. Am J Clin Nutr, 72, 647S- 52S.

4. Guyton, A.C. and Hall, J.E. 2008. Buku Ajar Fisiologi Kedokteran (Textbook of Medical Physiology).Edisi 11. Alih Bahasa: Irawati, dkk. EGC. Jakarta.

5. Harjanto. 2004. Recovery From Oxidative Stress in Physical Exercise. Jurnal Kedokteran Yarsi. 12 (3): 81-87.

6. Len, J., Davies, C.T., and Young, K. 2002. Changes in Indicators of Inflamation After Eccentric Exercise of the Elbow Flexors. Medical Science Sports Medicine. 25: 236-239.

7. Lukman H, 2003. Efek Antioksidan Vitamin E dan Vitamin C pada Cedera Trauma Kepala Berat. Medika Kartika Majalah Ilmiah Kedokteran Fakultas Kedokteran Ahmad Yani, Vol. 3 No. 1, April 2003.

8. Kiron V., J. Puangkaew, K. Ishizaka, S. Satoh, and T. Watanabe (2004) Antioxidant status and nonspecific immune responses in rainbow trout (Oncorhynchus mykiss) fed two levels of vitamin E along with three lipid sources. Aquaculture 234: 361-379

9. Kristo W, Damajanty H. C. P.,Joice N. A. Pengaruh pemberian vitamin E terhadap Kadar Neutrofil Setelah Latihan Fisik . Jurnal e-Biomedik (eBm), Volume 4, Nomor 2, JuliDesember 2016

10. Norong Perangin Angin.2011. Pengaruh Pemberian Vitamin E terhadap Kualitas Eritrosit yang Dipapari Tuak. Thesis. Program Magister Ilmu biomedik Fakultas Kedokteran Universitas Sumatera Utara

11. Pearce, J., J. E. Harris, and S. J. Davies (2003). The effect of vitamin E on the serum complement activity of the rainbow trout, Oncorhynchus mykiss (Walbaum). Aquacul Nut. 9: 337-340.

12. Senturk, U. K., Gunduz, F., Kuru, O., Aktekin, M. R., Kipmen, D., Yalcin, O., BorKucukatay, M., Yesilkaya, A. \& Baskurt, O. K. (2001), Exercise-induced oxidative stress affects erythrocytes in sedentary rats but not trained rats. J Appl Physiol, 91, 1999-2001.

13. Senturk, U. K., Gunduz, F., Kuru, O., Kocer, G., Ozkaya, Y. G., Yesilkaya, A., BorKucukatay, M., Uyuklu, M., Yalcin, O. \& Baskurt, O. K. (2004), Effect of oxidant vitamin treatment on the time course of hematological and hemorheological alteration after an exhausting exercise episode in human subject. J Appl Physiol, 98, 1272-79.

14. Senturk, U. K., Gunduz, F., Kuru, O., Kocer, G., Ozkaya, Y. G., Yesilkaya, A., BorKucukatay, M., Uyuklu, M., Yalcin, O. \& Baskurt, O. K. (2005), Exerciseinduced oxidative stress leads hemolysis in sedentary but not trained humans. J Appl Physiol, 99, 1434-4

15. Shojaei, E.A., Jafari, A., and Farajov, A. 2010. Effect of Acute Moderate Aerobic Cycling on Systemic Inflammatory Responses in Young Untrained Men. Science Sports. 2010: 1-5.

16. Sodique, N.O., Enyikwola, O., and Ekanem, A.U. 2000. Exercise-induced Leucocytosis in some Healthy Adult Nigerians. African Journal of Biomedical Research. 3: 85-88.

17. Yustini Alioes, Elmatris Sy. Efek pemberian Vitamin E terhadap Jumlah Ertrosit dan Aktivitas Enzim Katalase Tikus Akibat Paparan Sinar Ultraviolet. Majalah Kedokteran $\begin{array}{llllll}\text { Andalas, } & \text { Vol } & 33 & \text { No } & 2 & \text { Agustus }\end{array}$ http://jurnalmka.fk.unand.ac.id/index.php/art/issue/view/7 